\title{
PENGEMBANGAN APLIKASI BERBASIS MATLAB UNTUK MENGANALISIS SIFAT LASING KACA Te-Zn-Bi YANG TERDADAH ION $\mathrm{Er}^{3+}$
}

\author{
APPLICATION DEVELOPMENT BASED ON MATLAB TO ANALYZE THE NATURE OF LASING \\ GLASES Te-Zn-Bi DOPED BY Er ${ }^{3+} I O N$
}

\section{Rudi Susanto $^{1, a}$}

${ }^{1}$ STMIK Duta Bangsa Surakarta

Jl. Bhayangkara no. 55-57 Tipes, Surakarta

e-mail:arudist87@gmail.com

\begin{abstract}
Abstrak
Tujuan penelitian ini adalah mengembangkan aplikasi untuk menganalis sifat lasing kaca bahan penguat optik dengan parameter Judd-Ofelt. Pengembangan aplikasi menggunakan kaidah Software Development Life Cycle (SDLC) yang terdiri dari analisis, perancangan, pembangunan dan pengujian. Perancangan aplikasi mengunakan flowchart yang sesuai dengan kebutuhan dan pembangunan aplikasi mengunakan GUI matlab. Pengujian aplikasi mengunakan metode black box serta perbandingan hasil aplikasi dan perhitungan manual. Hasil pengujian menunjukan bahwa aplikasi mampu bekerja sesuai fungsionalitasnya yaitu digunakan untuk menganalisis sifat lasing kaca Te-Zn-Bi dengan doping $\mathrm{Er}^{3+}$ yang ditunjukan dengan output aplikasi berupa (1) Parameter $\Omega_{2}, \Omega_{4}, \Omega_{6}$, (2) Probabilitas Transisi, (3) Branching Ratio, (4) Life Time, (5) Omega4/ Omega6 serta(6) Aem/AESA. Output aplikasi tersebut merupakan parameter yang digunakan untuk menganalis sifat lasing sesuai parameter Judd Ofelt. Hasil perbandingan perhitungan manual dan aplikasi dapat diketahui bahwa rata-rata kesalahan relative adalah $1.2476 \%$. Dari hasil pengujian dapat disimpulkan bahwa aplikasi dapat digunakan untuk menganalisis sifat lasing.
\end{abstract}

Kata kunci: aplikasi, Judd-Ofelt, Software Development Life Cycle (SDLC), sifat lasing

\begin{abstract}
The purpose of this study was to develop an application to analyze the nature of the lasing material glass for optical amplifier by using Judd-Ofelt parameters. The Application development used the rules of Software Development Life Cycle (SDLC) that consists of analysis, design, development and testing. The Application design used a flowchart that was appropriate for the needs and implementation development by using GUI Matlab. The application testing used black box method and the comparison of the application's result and manual calculations. The testing results showed that the application was able to work according to the functionality that was used to analyze the nature of the lasing glass Te-Zn-Bi doped Er3+ ion indicated by the application's output in the form of (1) Parameter $\Omega_{-} 2, \Omega_{-} 4, \Omega \_6$, (2) Probability of Transition, (3) Branching Ratio, (4) Life Time, (5) Omega4 / omega6 and (6) AEM / AESA. The application output was the parameters used to analyze the nature of the lasing based on the Ofelt
\end{abstract}


Judd parameter. From the comparison results of the manual calculation and implementation, it could be seen that the average relative error was $1.2476 \%$. The testing results concluded that the application could be used to analyze the nature of lasing.

Keywords: application, judd ofelt, Software Development Life Cycle (SDLC), lasing properties Copyright@2016 Jurusan Fisika FMIPA Universitas Negeri Surabaya

\section{PENDAHULUAN}

Terdapat berbagai bahan yang digunakan untuk membuat penguat optik seperti borate, fluoride, germanite, silicate, phosphate, dan tellurite. Kaca telurite yang berbahan utama $\mathrm{TeO} 2$ memiliki beberapa keunggulan seperti indeks bias yang tinggi, fonon energi rendah, stabil terhadap kristalisasi, rentang transmisinya sangat lebar, dan kemungkinan untuk mendoping dengan ion tanah jarang dengan konsentrasi yang sangat besar [1]. Keunggulan tersebut yang menjadikan kaca Teurite mendapat perhatian peneliti di dunia. Untuk mendapatkan kaca tellurite yang dapat berfungsi sebagai penguat optik, kaca tellurite dapat didadah dengan ion tanah jarang, salah satunya adalah Erbium. Fungsi kinerja sebuah penguat optik secara umum dipengaruhi oleh probabilitas transisi dan lifetime [2].

Kaca Tellurite yang didadah ion $\mathrm{Er}^{3+}$ telah difabrikasi pada penelitian sebelumnya dengan komposisi $55 \mathrm{TeO}_{2}-2 \mathrm{Bi}_{2} \mathrm{O}_{3}-(43-\mathrm{x}) \mathrm{ZnO}-\mathrm{xEr}_{2} \mathrm{O}_{3}$ (TZB:Er) [3]. Karakteristik kaca Tellurite yang didadah ion $\mathrm{Er}^{3+}$ dianalisis dengan menggunakan teori Judd Ofelt. Analisis ini diperlukan untuk mengetahui sifat lasing dari kaca TZB:Er yang dihasilkan. Teori Judd Ofelt digunakan untuk menghitung probabilitas transisi radiatif dan radiatife lifetime suatu keadaan tereksitasi, serta cross section emisi terangsang dari ion tanah jarang [4].

Analisis Judd Ofelt dilakukan secara manual yakni dengan perhitungan dengan menggunakan Ms. Excel, perhitungan dengan menggunakan Ms.Excel memberikan hasil yang cukup baik [5]. Namun perhitungan secara manual ini masih sulit digunakan karena harus mengubah beberapa variabel didalam rumus perhitungan. Nilai variabel dalam analisis judd ofelt banyak sehingga berdampak pula pada formula yang harus dimasukkan kedalam Ms.Excel, selain itu perbedaan komposisi akan merubah nilai masukkan dan formula. Oleh karena itu pada penelitian ini dikembangkan aplikasi berbasis Matlab untuk menganalisis sifat lasing kaca TZB:Er dengan teori Judd Ofelt sehingga pengguna akan lebih mudah dalam melakukan analisis karakteristik lasing.

\section{METODE PENELITIAN}

Penelitian ini pada dasarnya ditujukan untuk membuat aplikasi yang digunakan untuk menganalisis sifat lasing kaca telurite yang didadah dengan Ion Erbium sebagai bahan penguat Optik. Metode pengembangan aplikasi menggunakan kaidah Software Development Life Cycle (SDLC) dengan tipe waterfall (air terjun) Gambar 1. Metode pengembangan aplikasi software ini meliputi :

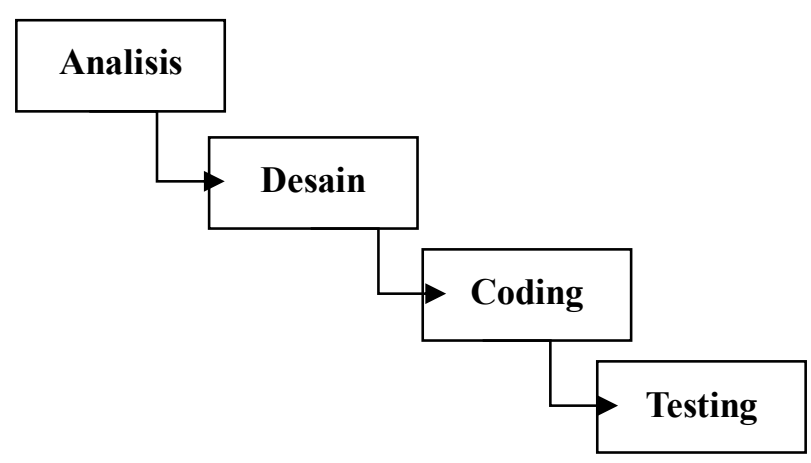

Gambar 1. Metode Pengembangan Aplikasi 


\section{a. Analisis}

Pada tahap ini dilakukan analisis terhadap kebutuhan aplikasi. Kebutuhan aplikasi tersebut meliputi formula yang akan digunakan dalam pembuatan aplikasi judd ofelt mengunakan matlab. Formula dalam penelitian ini akan disesuaikan dengan metode Judd-Offelt [6] [7]. Formula matematis yang akan digunakan meliputi: (1) Line strength (f) persamaan 1, (2) Judd-Offelt parameters $\Omega_{2}, \Omega_{4}$ and $\Omega_{6}$ persamaan 2, (3) Peluang transisi persamaan 3, (4) Branching ratio persamaan 4, (5) Lifetime persamaan 5 dan (6) Perbandingan intensitas emisi dan ESA persamaan 6 .

$$
\begin{aligned}
& f_{\text {meas }}=\frac{3 \operatorname{ch}(2 J+1)}{8 \pi^{3} e^{2} N} \frac{9 n}{\left(n^{2}+2\right)^{2}} \frac{2.3}{\lambda} \int_{J \rightarrow J^{\prime}} O D(\lambda) d \lambda(1) \\
& f_{\text {calc }}\left(J \rightarrow J^{\prime}\right)= \\
& \sum_{t=2,4,6} \Omega_{\mathrm{t}}\left|\left\langle(S, L) J\left\|U^{(t)}\right\|\left(S^{\prime}, L^{\prime}\right) J^{\prime}\right\rangle\right|^{2} \\
& A\left[(S, L) J ;\left(S^{\prime}, L^{\prime}\right) J^{\prime}\right]= \\
& \frac{3 c h(2 J+1)}{8 \pi^{3} e^{2} N} \frac{9 n}{\left(n^{2}+2\right)^{2}} f_{c a l c}(J \rightarrow \\
& \left.J^{\prime}\right) \sum_{t=2,4,6} \Omega_{\mathrm{t}}\left|\left\langle(S, L) J\left\|U^{(t)}\right\|\left(S^{\prime}, L^{\prime}\right) J^{\prime}\right\rangle\right|^{2} \\
& \beta\left[(S, L) J ;\left(S^{\prime}, L^{\prime}\right) J^{\prime}\right]=\frac{A\left[(S, L) J ;\left(S^{\prime}, L^{\prime}\right) J^{\prime}\right]}{\sum_{S^{\prime}, L^{\prime}, J^{\prime}} A\left[(S, L) J ;\left(S^{\prime}, L^{\prime}\right) J^{\prime}\right]}
\end{aligned}
$$

$\tau_{R}=\left[\sum_{S^{\prime}, L^{\prime}, J^{\prime}} A\left[(S, L) J ;\left(S^{\prime}, L^{\prime}\right) J^{\prime}\right]\right]^{-1}$

$\frac{A_{e m}}{A_{E S A}}=\frac{0,21 \Omega_{6}}{0,11 \Omega_{2}+0,063 \Omega_{4}}$

\section{b. Desain}

Pada tahap kedua desian penelitian dilakukan untuk pembuatan flow chart aplikasi yang dikembangkan, berbasarkan kajian pada tahapan pertama flow chart program dirancang seperti gambar 2 .

\section{c. Coding}

Tahap pembangunan atau coding adalah tahap pembuatan aplikasi sesuai sesuai dengan flow chart. Pengembangan aplikasi dilakukan dengan GUI matlab dengan formula sesuai dengan metode judd ofelt. Hasil akhir dari tahap ini adalah sebuah aplikasi desktop .

\section{d. Testing}

Pengujian aplikasi mengunakan metode black box untuk mengetahui fungionalitas aplikasi sesuai dengan tujuan pembuatan dan pengujian perbandingan dengan perhitungan manual. Dari tahap ini dapat diketahui fungsional aplikasi yang dibuat dan tingkat akurasi dibandingkan dengan perhitungan manual. 


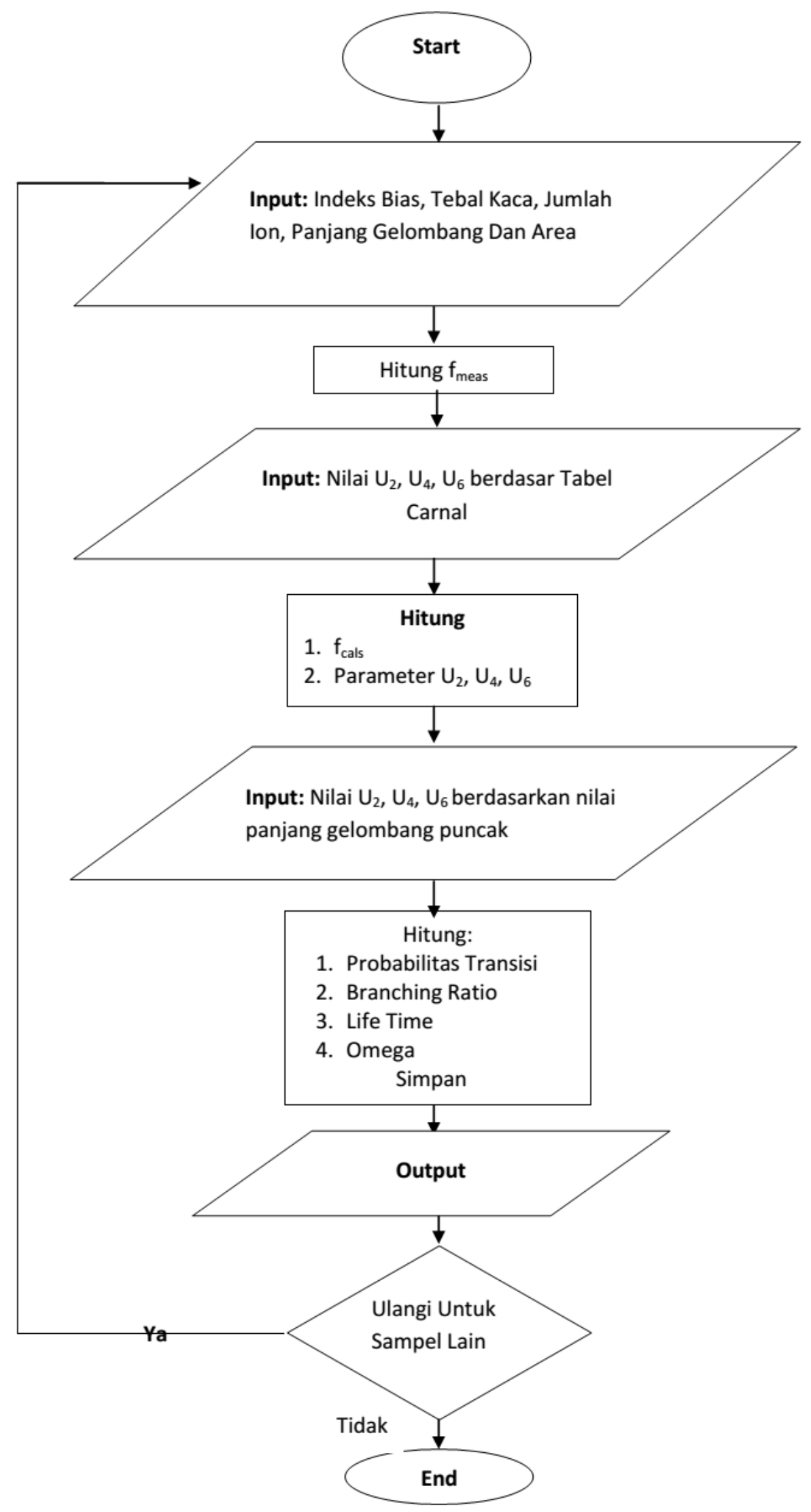

Gambar 2. Flowchart Aplikasi 


\section{HASIL PENELITIAN DAN DISKUSI}

Aplikasi dibuat berdasarkan perancangan

flowchart gambar 2, terdiri dari input dan output aplikasi. Input berupa Indeks Bias, Tebal Kaca, Jumlah Ion, Panjang Gelombang dan Area. Input aplikasi disesuaikan dengan komposisi55 $\mathrm{TeO}_{2}-2 \mathrm{Bi}_{2} \mathrm{O}_{3}-(43-\mathrm{x}) \mathrm{ZnO}-\mathrm{xEr}_{2}$
$\mathrm{O}_{3}$ (TZB:Er) dan hasil spektrum serapan pada daerah panjang gelombang 400 sampai $1100 \mathrm{~nm}$. Dari sampel kaca tersebut terdapat delapan puncak yaitu di sekitar panjang gelombang 408, 451, 489, 521, 544, 653, $799,980 \mathrm{~nm}$ atau sama dengan level energy berikut ${ }^{4} \mathrm{H}_{9 / 2},{ }^{4} \mathrm{~F}_{5 / 2},{ }^{4} \mathrm{~F}_{7 / 2},{ }^{4} \mathrm{H}_{11 / 2},{ }^{4} \mathrm{~S}_{3 / 2},{ }^{4} \mathrm{~F}_{9 / 2}$, ${ }^{4} \mathrm{I}_{9 / 2} \quad$ dan ${ }^{4} \mathrm{I}_{11 / 2}$.

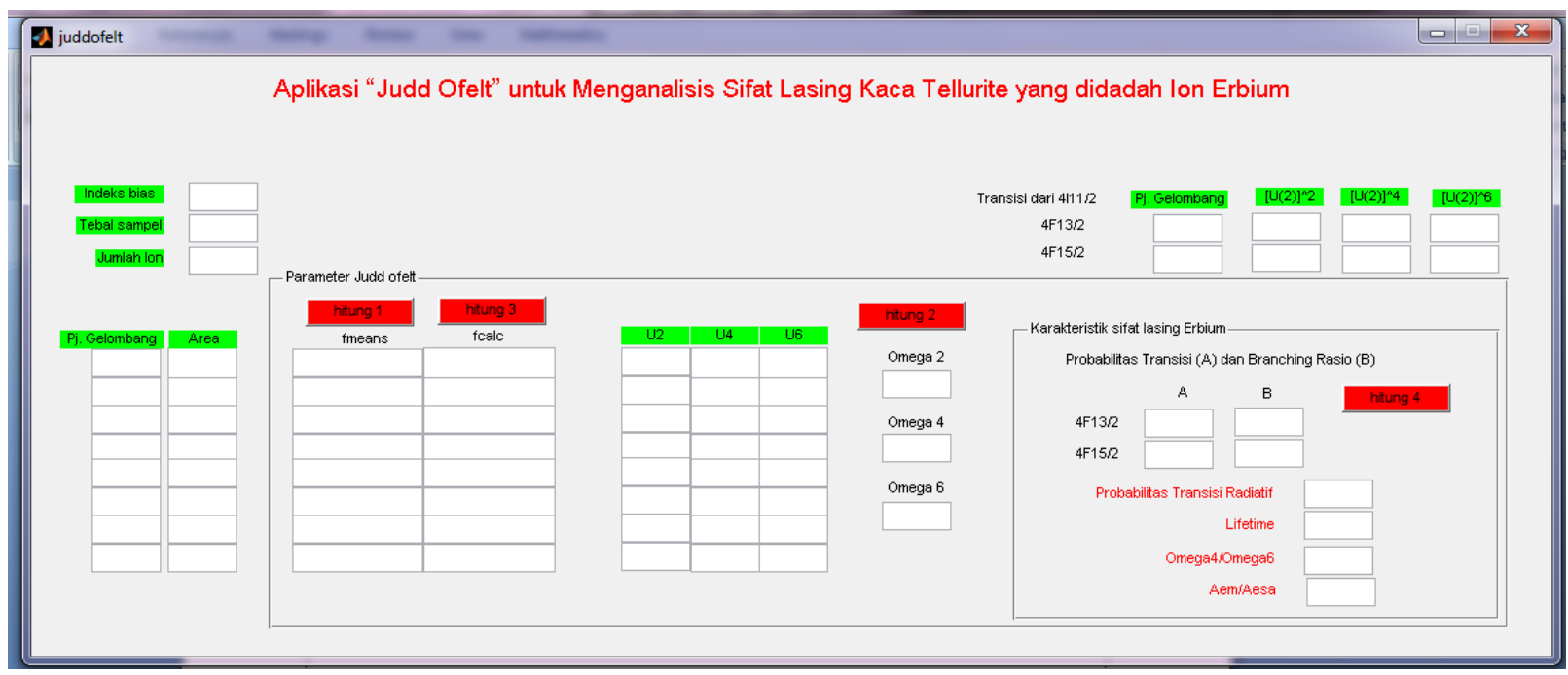

Gambar 3. Tampilan GUI Aplikasi

Tampilan antarmuka aplikasi disajikan dalam gambar 3. Tombol hitung 1 berfungsi melakukan perhitungan fmeas. Berikut adalah potongan listing program untuk tombol hitung 1 .

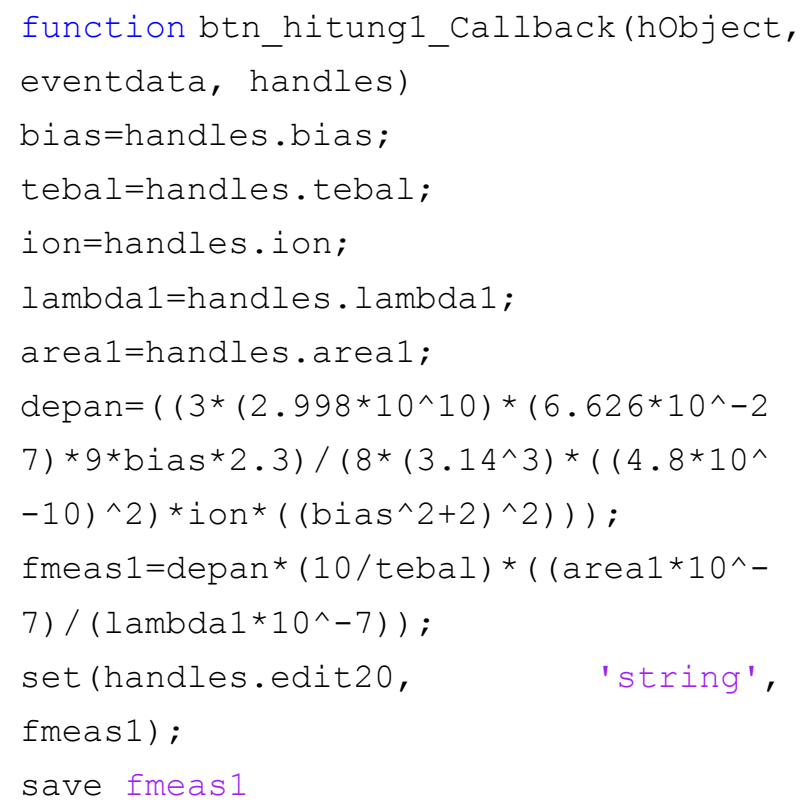

Input Nilai U2, U4, U6 berdasar [6] untuk menjalankan fungsi tombol hitung 2 dan 3 yaitu Parameter $\Omega_{2}, \Omega_{4}, \Omega_{6}$ dan fcals. Berikut adalah potongan listing program untuk hitung tombol hitung 2 dan 3 .

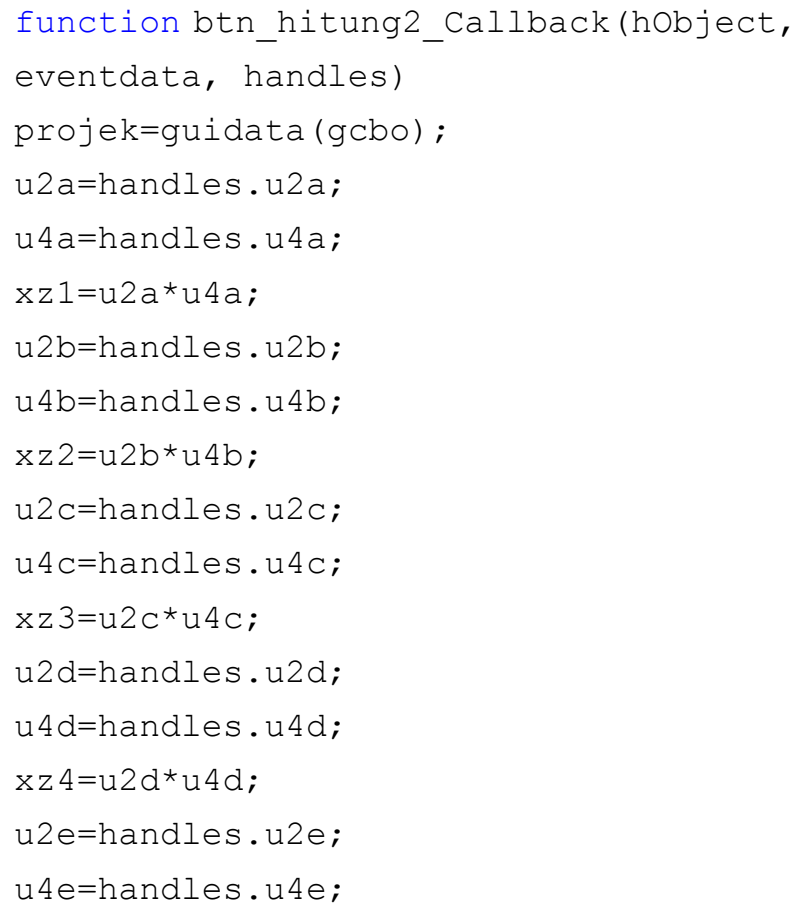




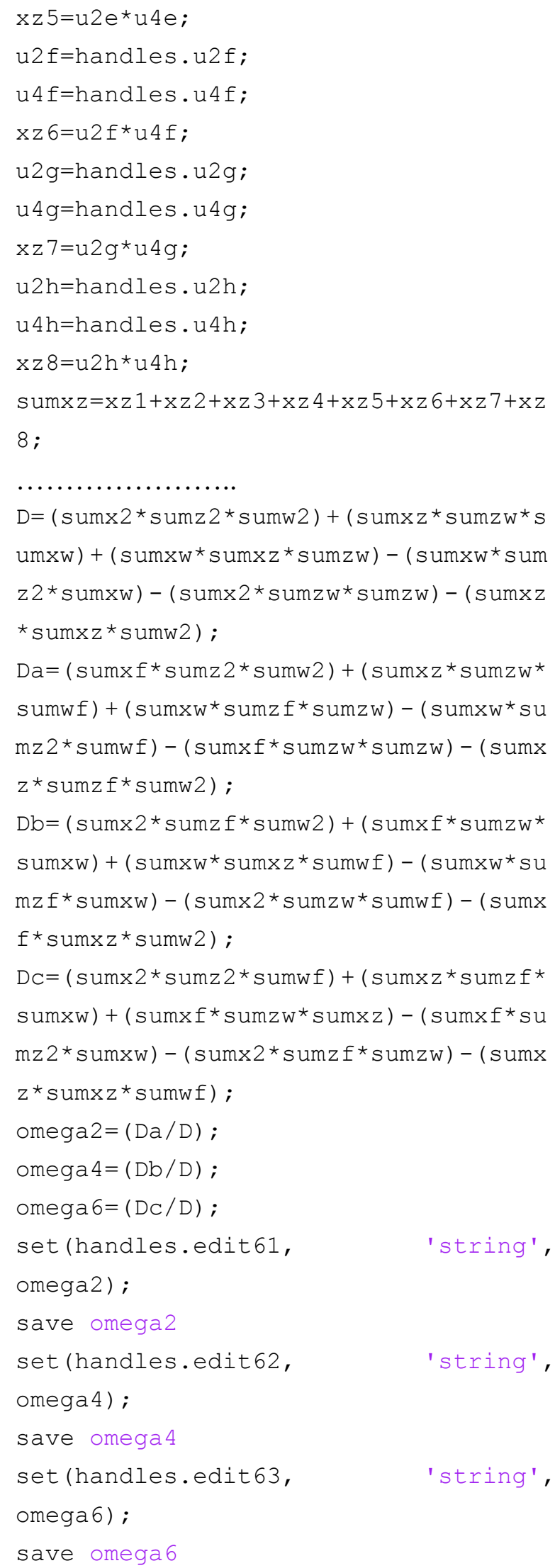

omeg2=str2num (get (handles.edit61, 'st ring'));

handles $. \circ \operatorname{omeg} 2=\operatorname{omeg} 2$;

omeg $4=$ str 2 num (get (handles.edit62, 'st ring'));

handles . omeg $4=$ omeg 4 ;

omeg $6=$ str 2 num (get (handles.edit63, 'st ring'));

handles . omeg $6=$ omeg 6 ;

u2a=handles.u2a;

u $4 \mathrm{a}=$ handles.u4a;

u $6 \mathrm{a}=$ handles.u6a;

fcalc $1=(($ omeg $2 * u 2 a)+($ omeg $4 * u 4 a)+($ ome g6*u6a)) ;

set (handles.edit52, 'string',

fcalc1):

save fcalcl

Hasil perhitungan pada hitung 1, 2, dan 3 serta Input Nilai U2, U4, dan U6 berdasarkan nilai panjang gelombang puncak untuk menjalankan fungsi tombol hitung 4 yaitu Probabilitas Transisi, Branching Ratio, Life Time, Omega4/Omega6 serta Aem/AESA. Berikut adalah potongan listing program untuk tombol hitung 4 :

function btn_hitung4_Callback(hobject, eventdata, handles)

projek=guidata (gcbo);

bias=handles.bias ;

omeg $2=$ str 2 num $($ get $($ handles.edit61, 'st ring')) ;

handles $\cdot$ omeg $2=$ omeg 2 ;

omeg $4=$ str 2 num (get (handles.edit62, 'st ring')) ;

handles. omeg $4=$ omeg 4 ; omeg $6=$ str 2 num (get (handles. edit63, 'st ring'));

handles . omeg $6=$ omeg 6 ;

lambda980=handles .1 ambda980 ;

u2980=handles.u2980;

u4980=handles.u4980;

u6980=handles.u6980; 


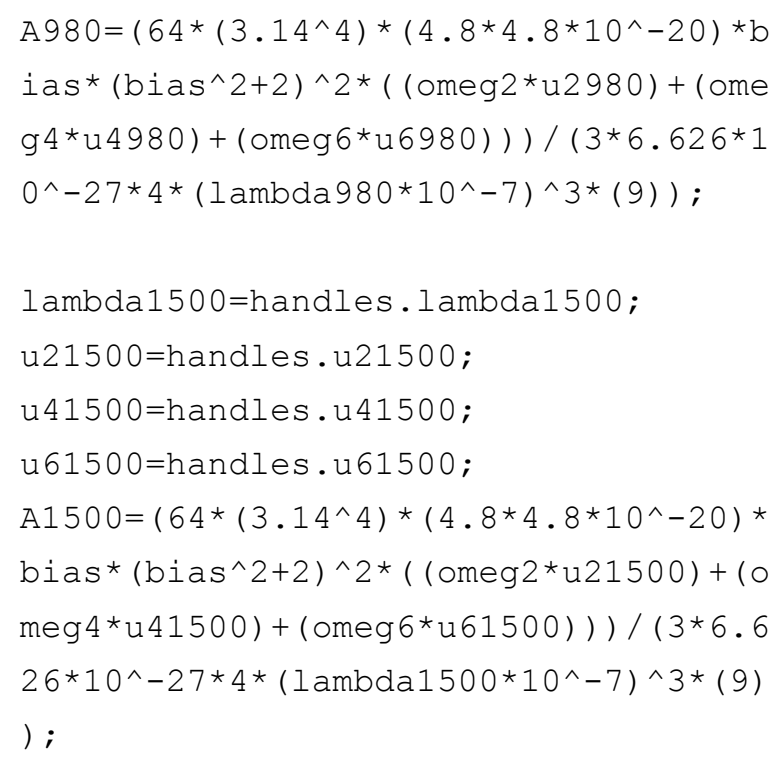

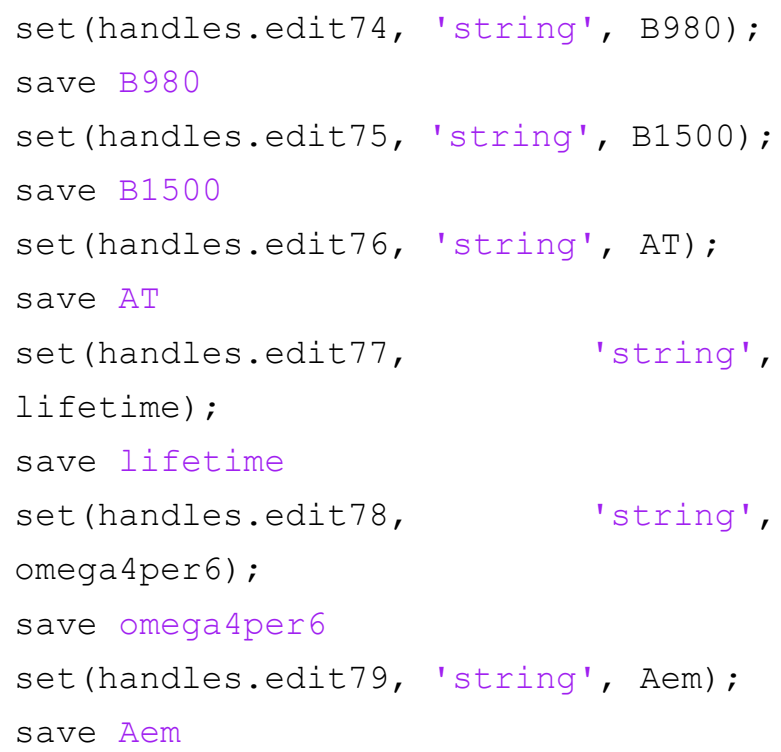

Hasil pengujian dengan metode blackbox terhadap fungsionalitas tombol hitung 1, 2, 3, dan 4 disajikan dalam Tabel 1 dan Gambar 4. Hasil pengujian menunjukan bahwa aplikasi mampu bekerja sesuai fungsionalitasnya yaitu digunakan untuk menganalisis sifat lasing Erbium Doped Fiber Amplifier yang ditunjukan dengan output aplikasi berupa (1) Parameter $\Omega_{2}, \Omega_{4}, \Omega_{6}$, (2) Probabilitas Transisi, (3) Branching Ratio, (4) Life Time, (5) Omega4/ Omega6 serta(6) Aem/AESA. Output aplikasi tersebut merupakan parameter yang digunakan untuk menganalis sifat lasing dari Erbium Doped Fiber Amplifier. .

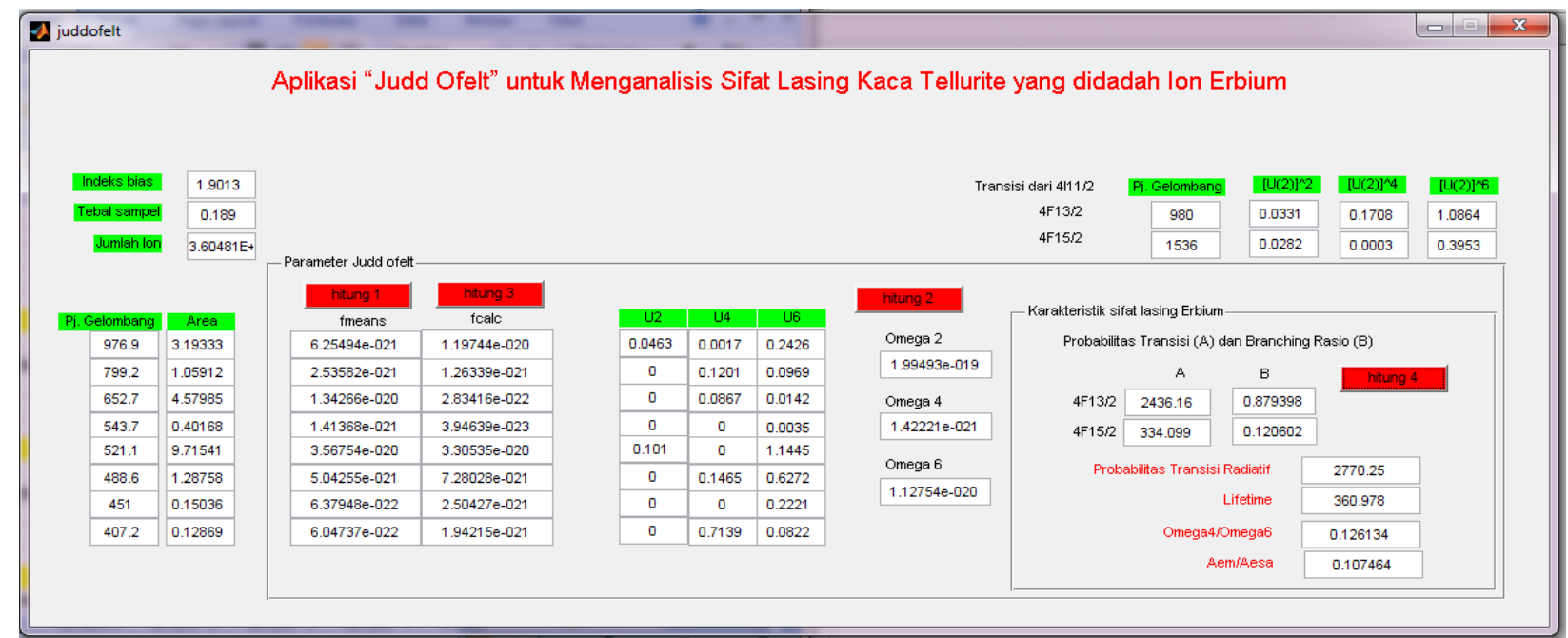

Gambar 4. Hasil pengujian black box 
Tabel 1. Hasil pengujian dengan metode blackbox

\begin{tabular}{|c|c|c|c|c|}
\hline No & Perlakuan & Hasil yang Diharapkan & Hasil Pengujian & Kesimpulan \\
\hline 1 & $\begin{array}{l}\text { Klik Tombol hitung } 1 \text { dan } \\
\text { Input Indeks Bias, Tebal } \\
\text { Kaca, Jumlah Ion, Panjang } \\
\text { Gelombang Dan Area }\end{array}$ & $\begin{array}{l}\text { Melakukan perhitungan } \\
\text { fmeas dan menyajikan dalam } \\
\text { kolom fmeas }\end{array}$ & $\begin{array}{l}\text { Perhitungan fmeas tampil } \\
\text { dalam kolom fmeas }\end{array}$ & Berhasil \\
\hline 2 & $\begin{array}{l}\text { Klik Tombol hitung } 2 \text { dan } \\
\text { Input Nilai U2, U4, U6 } \\
\text { berdasar Tabel Carnal }\end{array}$ & $\begin{array}{l}\text { Melakukan perhitungan } \\
\text { Parameter } \Omega_{2}, \Omega_{4}, \Omega_{6} \text { dan } \\
\text { menyajikan dalam kolom }\end{array}$ & $\begin{array}{l}\text { Perhitungan Parameter } \\
\Omega_{2}, \Omega_{4}, \Omega_{6} \text { tampil dalam } \\
\text { kolom } \Omega_{2}, \Omega_{4}, \Omega_{6}\end{array}$ & Berhasil \\
\hline 3 & $\begin{array}{l}\text { Klik Tombol hitung } 3 \text { dan } \\
\text { Input Nilai U2, U4, U6 } \\
\text { berdasar Tabel Carnal }\end{array}$ & $\begin{array}{l}\text { Melakukan perhitungan } \\
\text { fcals dan menyajikan dalam } \\
\text { kolom }\end{array}$ & $\begin{array}{l}\text { Perhitungan fcals tampil } \\
\text { dalam kolom fcals }\end{array}$ & Berhasil \\
\hline 4 & $\begin{array}{l}\text { Klik Tombol hitung } 4 \text { dan } \\
\text { Input Nilai U2, U4, U6 } \\
\text { berdasarkan nilai panjang } \\
\text { gelombang puncak }\end{array}$ & $\begin{array}{l}\text { Melakukan perhitungan } \\
\text { Probabilitas Transisi, } \\
\text { Branching Ratio, Life Time, } \\
\text { Omega4/ Omega6 serta } \\
\text { Aem/AESA dan menyajikan } \\
\text { dalam kolom }\end{array}$ & $\begin{array}{l}\text { Perhitungan Probabilitas } \\
\text { Transisi, Branching Ratio, } \\
\text { Life Time, Omega4/ } \\
\text { Omega6 serta Aem/AESA } \\
\text { tampil dalam masing } \\
\text { masing kolom }\end{array}$ & Berhasil \\
\hline
\end{tabular}

Tabel 2. Hasil perhitungan manual dan aplikasi $f_{\text {means }}\left(\mathrm{cm}^{2}\right)$

a. Komposisis 0,5 sampai 1,5 $\mathrm{mol}_{\%} \mathrm{Er}_{2} \mathrm{O}_{3}$

\begin{tabular}{|c|c|c|c|c|c|c|c|c|c|c|}
\hline \multirow{3}{*}{$\begin{array}{c}\text { Transisi } \\
\text { ke- }\end{array}$} & \multirow{3}{*}{$\begin{array}{l}\text { Panjang } \\
\text { Gelom-b } \\
\text { ang (m) }\end{array}$} & \multicolumn{9}{|c|}{$\mathrm{Er} 2 \mathrm{O} 3$ (\%mol) } \\
\hline & & \multicolumn{3}{|c|}{0.5} & \multicolumn{3}{|c|}{1.0} & \multicolumn{3}{|c|}{1.5} \\
\hline & & Manual & Aplikasi & Selisih & Manual & Aplikasi & Selisih & Manual & Aplikasi & Selisih \\
\hline${ }^{4} I_{11 / 2}$ & 980 & $6.25495 \mathrm{E}-21$ & $6.25476 \mathrm{E}-21$ & 0.00019 & $1.51556 \mathrm{E}-20$ & $1.51554 \mathrm{E}-20$ & 0.00001 & $9.39689 \mathrm{E}-21$ & $9.27744 \mathrm{E}-21$ & 0.11945 \\
\hline${ }^{4} \mathbf{I}_{9 / 2}$ & 799 & $2.53583 \mathrm{E}-21$ & $2.53575 \mathrm{E}-21$ & 0.00008 & $4.83330 \mathrm{E}-21$ & $4.83324 \mathrm{E}-21$ & 0.00006 & $3.08619 \mathrm{E}-21$ & $3.04696 \mathrm{E}-21$ & 0.03923 \\
\hline${ }^{4} \mathrm{~F}_{9 / 2}$ & 653 & $1.34267 \mathrm{E}-20$ & $1.34263 \mathrm{E}-20$ & 0.00004 & $3.18733 \mathrm{E}-20$ & $3.18729 \mathrm{E}-20$ & 0.00004 & $2.01632 \mathrm{E}-20$ & $1.99069 \mathrm{E}-20$ & 0.02563 \\
\hline${ }^{4} S_{3 / 2}$ & 544 & $1.41368 \mathrm{E}-21$ & $1.41364 \mathrm{E}-21$ & 0.00004 & $3.67228 \mathrm{E}-21$ & $3.67223 \mathrm{E}-21$ & 0.00005 & $2.34789 \mathrm{E}-21$ & $2.31805 \mathrm{E}-21$ & 0.02984 \\
\hline${ }^{4} \mathrm{H}_{11 / 2}$ & 521 & $3.56755 \mathrm{E}-20$ & $3.56744 \mathrm{E}-20$ & 0.00011 & $9.17185 \mathrm{E}-20$ & $9.17174 \mathrm{E}-20$ & 0.00011 & $5.80360 \mathrm{E}-20$ & $5.72983 \mathrm{E}-20$ & 0.07377 \\
\hline${ }^{4} \mathrm{~F}_{7 / 2}$ & 489 & $5.04256 \mathrm{E}-21$ & $5.04241 \mathrm{E}-21$ & 0.00015 & $1.48613 \mathrm{E}-20$ & $1.48611 \mathrm{E}-20$ & 0.00002 & $1.00818 \mathrm{E}-20$ & $9.95360 \mathrm{E}-21$ & 0.01282 \\
\hline${ }^{4} \mathrm{~F}_{5 / 2}$ & 451 & $6.37949 \mathrm{E}-22$ & $6.37930 \mathrm{E}-22$ & 0.00019 & $2.65151 \mathrm{E}-21$ & $2.65148 \mathrm{E}-21$ & 0.00003 & $1.73882 \mathrm{E}-21$ & $1.71671 \mathrm{E}-21$ & 0.02211 \\
\hline${ }^{2} \mathrm{H}_{9 / 2}$ & 408 & $6.04738 \mathrm{E}-22$ & $6.04720 \mathrm{E}-22$ & 0.00018 & $1.39699 \mathrm{E}-21$ & $1.39698 \mathrm{E}-21$ & 0.00001 & $9.48829 \mathrm{E}-22$ & $9.36768 \mathrm{E}-22$ & 0.12061 \\
\hline \multicolumn{2}{|c|}{ rata-rata selisih } & & & 0.00012 & & & 0.00004 & & & 0.05543 \\
\hline
\end{tabular}


b. Komposisi 2,0 sampai 3,0 mol\%Er2O3

\begin{tabular}{|c|c|c|c|c|c|c|c|c|c|c|}
\hline \multirow{3}{*}{$\begin{array}{c}\text { Transisi } \\
\text { ke- }\end{array}$} & \multirow{3}{*}{$\begin{array}{l}\text { Panjang } \\
\text { Gelom-b } \\
\text { ang (m) }\end{array}$} & \multicolumn{9}{|c|}{$\mathrm{Er} 2 \mathrm{O} 3(\% \mathrm{~mol})$} \\
\hline & & \multicolumn{3}{|c|}{2.0} & \multicolumn{3}{|c|}{2.5} & \multicolumn{3}{|c|}{3.0} \\
\hline & & Manual & Aplikasi & Selisih & Manual & Aplikasi & Selisih & Manual & Aplikasi & Selisih \\
\hline${ }^{4} \mathbf{I}_{11 / 2}$ & 980 & $4.51701 \mathrm{E}-21$ & $4.53251 \mathrm{E}-21$ & 0.01550 & $1.1254 \mathrm{E}-20$ & $1.12848 \mathrm{E}-20$ & 0.00595 & $1.7302 \mathrm{E}-20$ & 1. $72811 \mathrm{E}-20$ & 0.00206 \\
\hline${ }^{4} \mathbf{I}_{9 / 2}$ & 799 & $1.33222 \mathrm{E}-21$ & $1.33679 \mathrm{E}-21$ & 0.00457 & $3.28210 \mathrm{E}-21$ & 3.29099E-21 & 0.00890 & $5.3767 \mathrm{E}-21$ & 5.37033E-21 & 0.00640 \\
\hline${ }^{4} \mathrm{~F}_{9 / 2}$ & 653 & $7.78001 \mathrm{E}-21$ & $7.80671 \mathrm{E}-21$ & 0.02670 & $1.8892 \mathrm{E}-20$ & $1.89436 \mathrm{E}-20$ & 0.00512 & $3.5281 \mathrm{E}-20$ & $3.52391 \mathrm{E}-20$ & 0.00420 \\
\hline${ }^{4} S_{3 / 2}$ & 544 & $8.45710 \mathrm{E}-22$ & $8.48612 \mathrm{E}-22$ & 0.02902 & $1.89230 \mathrm{E}-21$ & $1.89743 \mathrm{E}-21$ & 0.00513 & $3.4089 \mathrm{E}-21$ & $3.40482 \mathrm{E}-21$ & 0.04006 \\
\hline${ }^{4} \mathrm{H}_{11 / 2}$ & 521 & $1.80301 \mathrm{E}-20$ & $1.80919 \mathrm{E}-20$ & 0.00618 & $3.798 \mathrm{E}-20$ & 3.80832E-20 & 0.01027 & $6.2425 \mathrm{E}-20$ & $6.23510 \mathrm{E}-20$ & 0.00743 \\
\hline${ }^{4} \mathrm{~F}_{7 / 2}$ & 489 & $3.20185 \mathrm{E}-21$ & $3.21284 \mathrm{E}-21$ & 0.01099 & 7.39230E-21 & 7.41233E-21 & 0.02003 & $1.5173 \mathrm{E}-20$ & $1.51552 \mathrm{E}-20$ & 0.00180 \\
\hline${ }^{4} \mathrm{~F}_{5 / 2}$ & 451 & $5.88637 \mathrm{E}-22$ & $5.90657 \mathrm{E}-22$ & 0.02020 & $1.3066 \mathrm{E}-21$ & $1.31015 \mathrm{E}-21$ & 0.00354 & $2.6454 \mathrm{E}-21$ & $2.64226 \mathrm{E}-21$ & 0.00315 \\
\hline${ }^{2} \mathrm{H}_{9 / 2}$ & 408 & 4.34564E-22 & $4.36056 \mathrm{E}-22$ & 0.01492 & $8.3522 \mathrm{E}-22$ & $8.37479 \mathrm{E}-22$ & 0.02263 & $1.4706 \mathrm{E}-21$ & $1.46883 \mathrm{E}-21$ & 0.00175 \\
\hline \multicolumn{2}{|c|}{ rata-rata selisih } & & & 0.01601 & & & 0.01020 & & & 0.00386 \\
\hline
\end{tabular}

Hasil pengujian perbandingan hasil perhitungan manual dan aplikasi $f_{\text {means }}$ (tombol hitung 1) disajikan dalam tabel 1a,1b. Dari hasil perbandingan perhitungan dapat diketahui bahwa rata rata selisih terbesar adalah 5,543\% pada komposisi 1,5 mol $\% \mathrm{Er}_{2} \mathrm{O}_{3}$ sedangkan hasil rata rata selisih terkecil adalah $0,004 \%$ pada komposisi 1,0 mol $\% \mathrm{Er}_{2} \mathrm{O}_{3}$ dengan rata-rata kesalahan relative adalah 1,2476\%. Dari Hasil perhitungan manual dan aplikasi dapat disimpulkan bahwa aplikasi dapat digunakan untuk menganalisis sifat lasing.

\section{KESIMPULAN}

Hasil pengujian black box menunjukkan bahwa aplikasi mampu bekerja sesuai fungsionalitasnya yaitu digunakan untuk menganalisis sifat lasing Erbium Doped Fiber Amplifier yang ditunjukan dengan output aplikasi berupa (1) Parameter $\Omega_{2}, \Omega_{4}, \Omega_{6}$, (2) Probabilitas Transisi, (3) Branching Ratio, (4) Life Time, (5) Omega4/Omega6, serta (6) Aem/AESA. Output aplikasi tersebut merupakan parameter yang digunakan untuk menganalis sifat lasing dari Erbium Doped Fiber Amplifier. Dari hasil perbandingan perhitungan manual dan aplikasi dapat diketahui bahwa rata-rata kesalahan relative adalah $1,2476 \%$. Dari Hasil pengujian dapat disimpulkan bahwa aplikasi dapat digunakan untuk menganalisis sifat lasing.

\section{UCAPAN TERIMA KASIH}

Terima kasih kepada saudara Ike Yusliastuti yang telah membantu dan memberikan pencerahan dalam pembuatan aplikasi ini. Terima kasih juga kami ucapkan untuk Tim di LPPM STMIK Duta Bangsa Surakarta.

\section{DAFTAR PUSTAKA}

[1] Weber M. Handbook of Optical Materials. CRC Press: New York; 2002.

[2] Ghoshal SK, Sahar MR, Rohani MS, dan Sharma S. Temperature dependent luminescence in erbium-doped zinc tellurite glass: A model investigation. Indian Jurnal of Pure \& Applied Physics. 2011; 49: 509-515. Terdapat pada:

http://nopr.niscair.res.in/bitstream/12345678 9/12452/1/IJPAP\%2049\%288\%29\%20509-5 15.pdf

[3] Susanto $\mathrm{R}$ dan Marzuki A. Pengaruh Konsentrasi Ion Erbium pada Sifat Fisik dan Optik Kaca Telurium Oxide sebagai Bahan Penguat Optik. Jurnal Materi dan Pembelajaran Fisika (JMPF). 2014; 4(1). Terdapat pada:

http://jurnal.fkip.uns.ac.id/index.php/fisika/a rticle/view/5397/3813 
[4] Sazali et al. Journal of Non-Oxide Glasses. 2014; 6(4): $61-67$.

[5] Yuliasuti I, Rahmasari L, dan Riyatun. Pembuatan Aplikasi Program Matlab untuk Menganalisa Sifat Lasing Kaca TZBN Yang Didadah Ion $\mathrm{Nd} 3+$ sebagai Bahan Material Host Laser. Jurnal Fisika Indonesia. 2014; 18(54): 97-102. Terdapat pada: http://pdm-mipa.ugm.ac.id/ojs/index.php/jfi/ article/view/896
[6] Sardar DK, et al. Judd-Ofelt analysis of the Er3+ (4f11) absorption intensities in Er3+-doped garnets. Journal of Applied Physics. 2003; 93(5). DOI: $\underline{10.1063 / 1.1543242}$

[7] Marzuki A. Laser Analysis of Nd3+ Ions in Fluoroaluminate Glasses. Jurnal Matematika dan Sains. 2007; 12(1): 32-37. Terdapat pada: http://jms.fmipa.itb.ac.id/ojs_3.0.2/index.ph $\mathrm{p} / \mathrm{jms}$ 